\title{
PARASITIC DISEASES OF FISH
}

Muhammad Imran ${ }^{1^{*}}$, Muhammad Sohail Sajid', Sara Omer Swar², Muhammad Kasib Khan' ${ }^{1}$, Muhammad Abdullah Malik and Amna Ahmad ${ }^{1}$

'Department of Parasitology, University of Agriculture, Faisalabad, Pakistan

${ }^{2}$ Department of Food Technology, College of Agricultural Engineering Sciences, Salahuddin University Kurdistan, Iraq

*Corresponding author: imran.asghar@uaf.edu.pk; Cell: +92-333-8387702

\section{INTRODUCTION}

The fishes (Phylum: Chordata) are the most diversified group of aquatic organisms known as cold-blooded vertebrates. They have gills and fins for breathing and swimming, respectively. Different kinds of fishes protect themselves with scales and have an efficient body for convincing movement in water (Tedesco et al. 2017). Moreover, fish is considered as an important part of human food and playing a significant role in the economy of various states worldwide (Essetchi et al. 2003; Andronova and Yakimovich 2019). There are around 28,900 species of fish present in the world, 13,00o species are known as freshwater, having 170 families and 2,513 genera, which are found in rivers and lakes $(1 \%$ of the total water available on earth), whereas the remaining 16,000 species are found in saline medium (covering $70 \%$ of the earth) (Leveque et al. 2008). This chapter describes the parasitic threats to profitable fish farming around the globe.

\section{Parasitic fauna of fish}

Fish is directly or indirectly affected by different kinds of parasites, which cause high mortality in this species. Four major groups of parasites that cause infections in fish are: Protozoa (ciliates, flagellates, microsporidians, myxozoans), platyhelminthes (monogenean, digenean, cestodes), nemathelminthes, and acanthocephala. The physiology of fish facilitates the occurrence of various lethal diseases, which lead to mass mortality (Al Marjan and Abdullah 2009; Lerssutthichawal et al. 2015). Furthermore, fish act as hosts for numerous parasites; especially gastrointestinal (GI) helminths which are considered major fish parasites, causing intensive losses to the fish industry. Parasites affect the diet, metabolism, and secretory functions of the digestive system, which causes severe damage to the nervous system and interrupts the normal reproduction of the fish. The parasitic threats are the major reason for the reduction in the fish population (Habib 2007). Parasitic fauna infecting various systems of fish is given in Table 1.

\section{Protozoan parasites of fish}

Protozoans are the significant parasites of fish kept under intensive fish culture. The major groups of protozoa infecting the fish are myxozoans, microsporidians, ciliates, and flagellates (Wang et al. 2019). These parasites can increase their number when the host fish is overcrowded, resulting in weight loss, emaciation, and mortality (Gomes et al. 2017). Among different groups of protozoans, ciliates and flagellates have a direct life cycle and mostly infect the pond water fish. On the other hand, microsporidians are intracellular and require tissue of the host for reproduction (FAO 2015). The fish became infected by ingesting spores from the infected fish or food sources (Manbe et al. 2020). The cells having the parasites start to increase in size to accommodate the proliferation (merogonous and sporogonous development) of the parasite (Wang et al. 2019; Agboola et al. 2021). The multiplication of these sporozoites inside the cell causes the development of tumor-like masses in various tissues of the fish (Saha and Bandyopadhyay 2017). The pathological lesions that occur due to these cancer-like growths include multiple whitish nodules on the tissues, and thickening of the wall of gall bladder (FAO 2015). Acute anemia may result in the case of microsporidian infection of haemopoietic cells (Maciel et al. 2018).

Myxozoan parasites infect many groups of fish, including Cichlidae, Cyprinidae and Mugilidae (FAO 2015). In Africa, more than 135 species of myxozoans are known to cause infection in fish of all habitats i.e., freshwater, brackish water and marine water habitats (Santos et al. 2018). More than 17 species from four different genera of parasites including Henmeguya, Myxobolus, Myxobilatus and Parahenmeguya have been reported to infect the fish. Infra-communities and component communities are being formed by the myxozoan parasites which can surpass the colonies formed by other parasites (Balta et al. 2019). These myxozoan parasites can cause histozoic and coelozoic infections (FAO 2015). The signs of the former include, whitish cyst containing milky fluid with microscopic spores, which can be seen on the scales, fins, lips, and around eyes. It has been further reported that the infection may cause breaking of the cartilage of gills, resulting in disturbed breathing and inadequate gaseous exchange (Maciel et al. 2018). In cultured fish, several Myxozoan infections have been reported i.e, skeletal deformities, locomotory disturbances, emaciation, sunken eyes in the brain, and circulatory dysfunctions at the base of the gill lamellae (Santos et al. 2018; Manbe et al. 2020). The simplified life cycle of protozoan parasites infecting the fish has been elaborated in Fig. 1. 
Table 1: List of parasitic fauna harboring various fresh and salt-water fish fauna around the world
Sr. Parasite Name
Site of Infection
Host
Disease
Source
\# (Common name)

Parasites of integument \& skeletal system

1. Amyloodinium Gills \& Skin All types of fishes

Ocellatum

2. Trichodina

Gills \& Skin

3. Cryptocaryon irritans Skin, Fins, Gills

Skin

4. Ichthyophthirius multifiliis

5. Monogeneans

Skin \& Gills

6. Isopods

Gills \& Body surface

7. Brooklynella hostilis

Skin \& Gills

All types of fishes

\section{All \\ Marine Fishes}

All

Goldfish, channel catfish, angelfish Epinephalus (Ep.) coidois, Ep. malabaricus

Damselfish, Amphiprioninae
Amylodiniosis/Marine velvet (Moreira 2017) disease

Trichidiniasis (Nofal 2017)

Cryptocaryonosis/White

(Liu 2020) spot disease

Ichthyophithiriasis/white (Buchmann 2020) spot disease / Ich

Skin and gill monogean disease

(Neves 2020)

(Purivirojkul

2020)

Brooklynellosis/Clownfish (Anshary 2020) Disease

Parasites of eye

1. Diplostomum

Eye

spathaceum

(Eye Fluke)

Fresh water and brackish

water fishes

Diplostomiasis

(Vyhlídalová 2020)

Parasites of vascular system

\begin{tabular}{|c|c|c|c|c|c|}
\hline 1. & $\begin{array}{l}\text { Sanguinicola } \\
\text { occidentalis }\end{array}$ & Heart & Perca jlavescens & Sanguinicoliasis & (Muzzall 200o) \\
\hline 2. & Paradeonta cylix & Heart & Greater amberjack & Blood fluke disease & $\begin{array}{l}\text { (Repullés-Albelda } \\
\text { 2008) }\end{array}$ \\
\hline 3. & Cardicola & Blood & $\begin{array}{l}\text { Northern Bluefin tunna } \\
\text { thynnus }\end{array}$ & - & (Shirakashi 2016) \\
\hline 4 . & Trypanoplasma sp. & Vascular system, kidneys & Blue tilapia fish & - & (Carrington 2017) \\
\hline 5 . & $\begin{array}{l}\text { Crassiphiala } \\
\text { bulboglossa }\end{array}$ & Blood & Vermont fish & - & (Achatz 2019) \\
\hline 6. & Aporocotylid digenean & $\begin{array}{l}\text { Heart, Gills, Cranial \& } \\
\text { mesenteric Blood vessels }\end{array}$ & Fresh and marine water fish & Black grub & $\begin{array}{l}\text { (Poddubnaya } \\
\text { 2021) }\end{array}$ \\
\hline \multicolumn{6}{|c|}{ Parasites of the central nervous system } \\
\hline 1. & Tetrahymena corlissi & Skin, Eye \& Muscles & Fresh water fishes' guppies & - & (Imai 200o) \\
\hline 2. & Uronema Nigricans & $\begin{array}{l}\text { Connective tissues (Skin, } \\
\text { Fins \& Nervous Tissues) }\end{array}$ & $\begin{array}{l}\text { Bluefin tuna } \cdot \text { Thunnus } \\
\text { maccoyi }\end{array}$ & - & (Arévalo 2018) \\
\hline 3. & $\begin{array}{l}\text { Myxosoma (My.) } \\
\text { cerebralis/ Myxobolus } \\
\text { (M.) cerebralis }\end{array}$ & $\begin{array}{l}\text { Head, Cartilage \& } \\
\text { backbone }\end{array}$ & Salmon and trout & Whirling disease & (Alexander 2020) \\
\hline \multicolumn{6}{|c|}{ Parasites of viscera and musculature } \\
\hline 1. & $\begin{array}{l}\text { Contracaecum } \\
\text { rudolphii }\end{array}$ & $\begin{array}{l}\text { Body Cavities \& visceral } \\
\text { organs }\end{array}$ & All types of fishes & - & (Baruš 2001) \\
\hline 2. & Sphaerospora renicola & Kidneys & Cyprinids & Renal dropsy & $\begin{array}{l}\text { (Eszterbauer and } \\
\text { Székely 2004) }\end{array}$ \\
\hline 3. & $\begin{array}{l}\text { Posthodiplostomum } \\
\text { cuticula }\end{array}$ & $\begin{array}{l}\text { Viscera, Heart \& } \\
\text { Posterior kidney }\end{array}$ & Freshwater fishes & Black spot disease & $\begin{array}{l}\text { (Ondračková } \\
\text { 2004) }\end{array}$ \\
\hline 4 . & $\begin{array}{l}\text { Diphyllobothrium } \\
\text { latum (Broad fish } \\
\text { tapeworm) }\end{array}$ & Viscera \& Musculature & Fresh water fishes & Diphyllobothriasis & (Scholz 2009) \\
\hline 5 . & $\begin{array}{l}\text { Proteocephalus } \\
\text { ambloplitis }\end{array}$ & Ovary & Freshwater fishes & - & (Scholz 2019) \\
\hline 6. & Bolbophorus confuses & Skeletal muscle \& Viscera & Channel catfish & $\begin{array}{l}\text { Channel virus disease or } \\
\text { enteric septicemia like } \\
\text { condition }\end{array}$ & (Doffitt 2020) \\
\hline 7 . & $\begin{array}{l}\text { My. cerebralis / } M \text {. } \\
\text { cerebralis }\end{array}$ & $\begin{array}{l}\text { Head, Cartilage \& } \\
\text { backbone }\end{array}$ & Salmon and trout & Whirling disease & (Alexander 2020) \\
\hline \multicolumn{6}{|c|}{ Parasites of the alimentary canal } \\
\hline 1. & $\begin{array}{l}\text { Glugea (Gl.) hertwigi } \mathcal{E} \\
\text { Gl. stephani, }\end{array}$ & $\begin{array}{l}\text { Submucosa of GI \& } \\
\text { Mesentery }\end{array}$ & Smelt, marine flatfishes & $\begin{array}{l}\text { Non-functional, } \\
\text { granulomatous bulged out } \\
\text { abdomen }\end{array}$ & (Ogawa 1998) \\
\hline 2. & $\begin{array}{l}\text { Bothriocephalus } \\
\text { acheilognathi }\end{array}$ & Intestine & Carps and other cyprinids & $\begin{array}{l}\text { Haemorrhagic enteritis/ } \\
\text { Gowkongensis }\end{array}$ & $\begin{array}{l}\text { (Salgado- } \\
\text { Maldonado 2003) }\end{array}$ \\
\hline 3. & Cryptobia iubilans & Stomach & African cichlids & Cryptobiosis & (Woo 2003) \\
\hline 4 . & Balantidium & Intestinal lumen & Marine and Fresh-water fish & $\begin{array}{l}\text { Catarrhal enteritis and } \\
\text { ulceration }\end{array}$ & (González 2005) \\
\hline
\end{tabular}


5. Goussia (G.) subepithelialis, $G$. Carpelli

6. Cryptosporidium

7. Ceratomyxa shasta

8. Pseudophyllid Triaenophorus

9. Spironucleus

10. Caryophyllidea

11. Contracaecum

12. Camillanus

13. Philometra

14. Eustrongylides

15. Capillaria

16. Crepidostomum

17. Enteromyxum (E.) leei, Intestinal Epithelium E.scophthalmi

18. Acanthocephalus

Stomach

Posterior Intestine Intestine

Intestine

Intestine

Alimentary tract

Alimentary tract

Ovaries

Viscera \& Muscles

Intestine

Intestine Intestinal lumen
Intestinal epithelial cells Carps, marine and freshwater Coccidiosis fishes

Body cavity, Tissues \&
Marine tropical fish

Salmonids

Wild and cultivated salmonids Chronic haemolytic

Cryptosporidiosis (necrosis of gastric epithelium)

Ceratomyxosis

Anaemia

Salmonids, All cichlids, bettas, "Hole in the head" disease gouramis, other aquarium snd freshwater fishes

Cyprinid and catostomid fish, Intestinal nodules and ulcers (Barčák 2014)

Largemouth bass, centrarchids Anisakidosis

Largemouth bass, other

centrarchids

Marine fish

"Parasitic Castration" in

female fish

Angelfish, other aquarium and Eustrongylidosis

freshwater species

Angelfish, discus, other Capillariasisis

aquarium fish

Salmonids In the Nearctic and Enteritis

Palearctic regions

Tiger puffer fish, marine and Enteritis

fresh-water fish

Wild-caught freshwater fishes, Necrotic haemorrhagic wild-caught marine fish

(Younis 2017)
(Pasnik 2005)

(Méndez-

Hermida 2007)

(Bjork 2010)

(Hoole 2010)

(Williams 2011)

(Manickam 2018)

(Ali 2018)

(Guagliardo 2019)

(Abdel-Rahman 2019)

(Faltýnková 2020)

(Picard-Sánchez 2020)

(Nakao 2021)

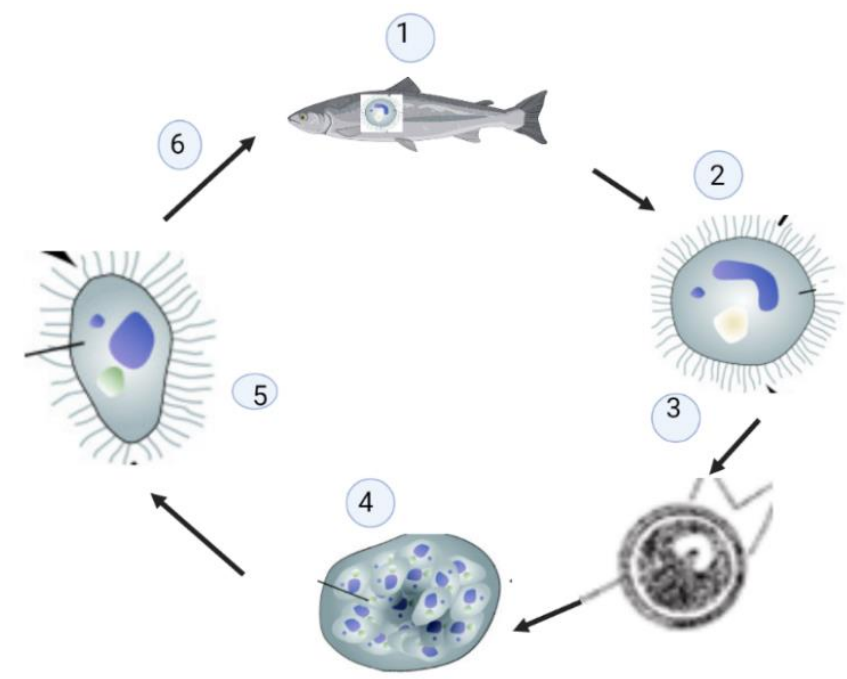

Fig. 1: Simplified life cycle of protozoan parasites infecting the fish: $1=$ Trophont feeds on fish, $2=$ mature tomont leaves the host, $3=$ Tomont secretes gelatinous cyst wall, $4=$ Tomont undergo cell division and produce daughter tomites, $5=$ Tomites differentiate into infective Theronots, $6=$ Theronts bore through the cell wall and infect the fish (Source: Modified from Roberts 2012).

\section{Helminths parasites of fish}

Helminths are the biggest group of parasites infecting the fishes. More than 30,00o helminth species are infecting the sea and freshwater fish and some of them are known to cause serious fish diseases or may represent an important public health concern (Williams and Jones 1994). Platyhelminthes (flatworms: cestodes, monoge-neans and digeneans); Nemathelminthes (roundworms: nematodes) and Acanthocephalan (thorny-headed worms) are major groups of helminths parasites (Nguyen et al. 2020).

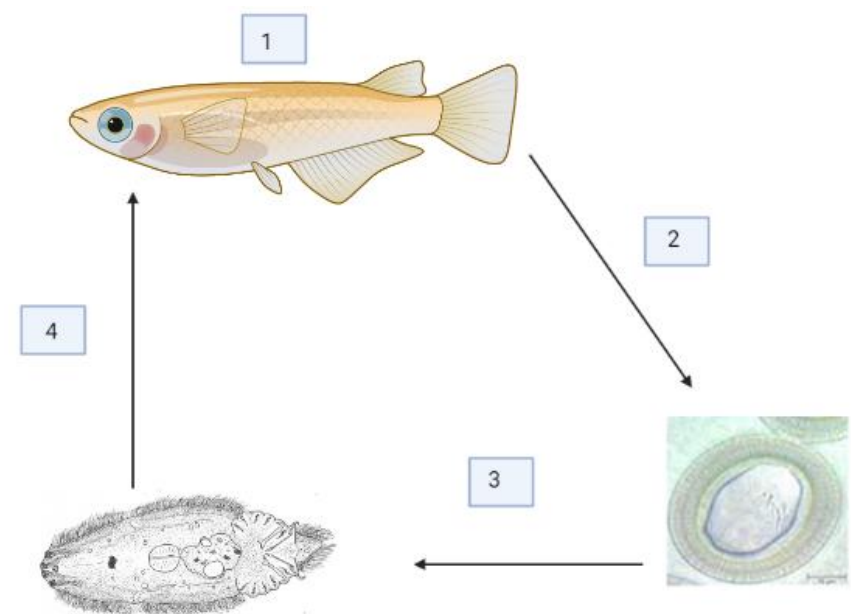

Fig. 2: Simplified life cycle of Monogeneans parasites infecting the fish: $\mathbf{1}=$ Adults present on fish skin and gills, $\mathbf{2}=$ Eggs laid by adult, 3=Eggs hatch ad release oncomiracidium, 4=Free swimming oncomiracidium attaches to the host (Source: Modified from Roberts 2012).

\section{Trematodes}

Trematodes, also known as flatworms or flukes, are a class of helminths which are further classified into monogeneans and digeneans. Their site of infection is the skin, fins and gills of the teleost that inhabit freshwater and brackish water (Antar and Gargouri 2018).

\section{Monogeneans}

Naturally, monogeneans are host-specific (Saad-Fares 1992). They are hermaphrodites and at the anterior end possess sensory structures, a mouth with or without accessory suckers, special glands and clamps for the 
attachment to the host. Mostly they reside on the body surface of the host like epidermis, scales, fins, gills, lip folds, nares, and branchiostegal membranes. They have a direct life cycle, without the involvement of an intermediate host (Buchmann 2002).

There are three main taxa of monogeneans; Dactylogyroidae, Caspaloidae and Polyopisthacotylea. Dactylogyroidae family members are relatively smaller in size and are usually present in inland fishes as compared to the Caspaloidae and Polyopisthacotylea, which are larger and mostly found in marine fishes. Due to their different taxa, they are slightly different in their structure and nature of infection like Dactylogyroids are oviparous, while Gyrodactylidae is viviparous. The former consists of one or two anterior-dorsal pairs of eyes and posteriorventral opisthaptor, while later possesses no eyespots and two pairs of anchor hooks. Dactylogyroids inhabit the gills of fish, while gyrodactylidae reside on the skin and fins. Some of them occasionally infest nasal cavities, stomach, or urethra of freshwater fishes (Šimková 2017). In their natural habitats, fish can co-exist with monogeneans but some of them like gonodactylids can be pathogenic, predominantly to the young fishes.

Dactylogyrus (D.) vastator is the parasite of carp fry fish and infests the gills of the host, causing epithelial hyperplasia intervening in the respiratory system that leads to death of the host. D. extensus is also a deadly parasite of the young, as well as adult, fishes (Dzika 2009). D. groschefti has shown more than $90 \%$ mortality rates in young Clarias gariepinus (Hansen 2003). Macrogylodactylus mostly affect aquaculture fishes viz Clarias, Lates niloticus, and Anabantidae species (Iyaji 2008). Parasitic infestation is dependent on several physical and chemical factors. Physical components may include temperature and depth of the pond, while oxygen and salinity levels are the main chemical features. Temperature is generally the main element for seasonal parasitic prevalence (Gopko 2020).

\section{Digeneans}

Digeneans trematodes are a very diverse group of fish parasites, belonging to 15 families and more than 50 species (Selbach 2020). They mostly parasitize freshwater fishes and can act as internal or external parasites involving several organs. They have complex, indirect life cycle and are heteroxenous in nature due to the involvement of multiple intermediate hosts and larval stages in their life cycle. Bivalves and gastropod mollusks act as their intermediate hosts. Their metacercariae are present in large numbers within-host and affect several tissues and organs. Lesions appear depending upon the organ involved. Sanguinicola species are parasites of Synodontis schall and Auchinoglanus occidentalis. It is commonly known as blood fluke because worms and eggs are present in blood and may cause thrombosis and subsequent necrosis. On the other hand, migration of miracidia through the gills epithelium leads to direct blood loss, followed by anemia. They cause damage to the heart, brain, eyes, and other soft organs (Kirk 2012).
Syphodera ghanensis and Aspidogaster africanus infect the intestines of Chrysichthyes nigrodigitatus and cause intestinal destruction of the host (Kohn et al. 2007). The general life cycle of trematode parasites is elaborated in Figs. 2 and 3.

\section{Cestodes}

Cestodes are commonly called as tapeworms due to their ribbon-like and multisegmented body structure. Their characteristic feature is host specificity; cestodes generally affect members of siluriform. They are mainly divided into two forms namely, the monozoic forms notably Caryophyllaeidae, and the amphilinid represented by the segmented Pseudophyllideans and Proteocephalideans.

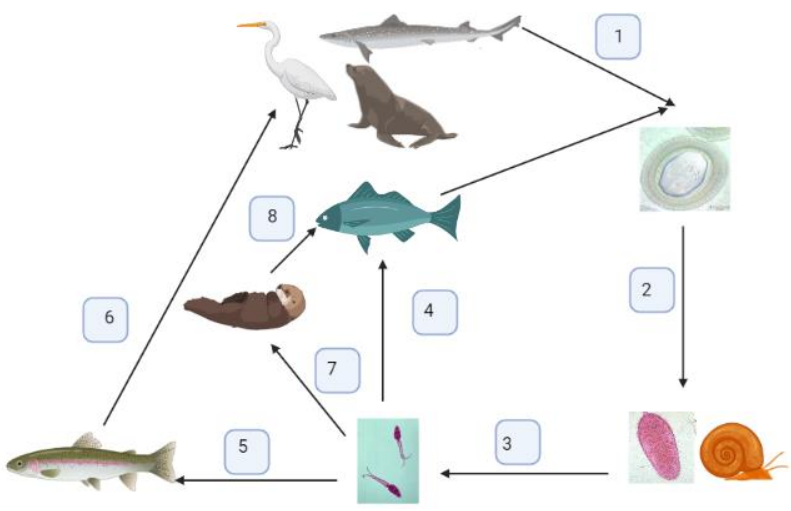

Fig. 3: Simplified life cycle patterns of Digeneans parasites infecting the fish: 1=Eggs released from final host, $2=$ Egg hatch into miracidium which invades molluscan host, 3=Larval development resulting in the production of cercariae, $4=$ Cercariae direct invaded final host, $5=$ Cercariae released invades fish intermediate host, $6=$ Cercariae develop into metacercaria in intermediate host and this metacercaria invades final host, $7=$ Cercariae invades invertebrates intermediate host, 8=Encysted metacercaria eaten by final host (Source: Modified from Roberts 2012).

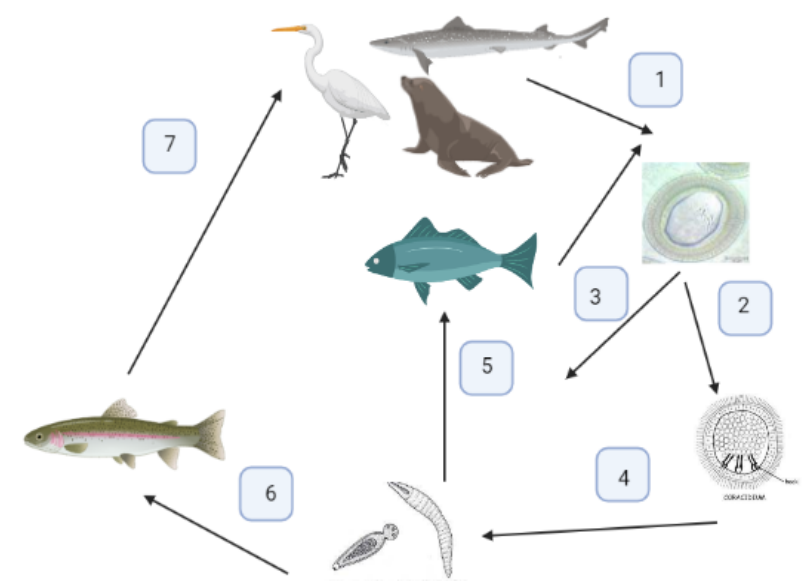

Fig. 4: Simplified life cycle patterns of cestodes parasites infecting the fish, $\mathbf{1}=$ Eggs laid by final adult host, $\mathbf{2}=$ Egg hatch and release coracidium, 3=Eggs eaten by invertebrate intermediate host, $4=$ Coracidium eaten by intermediate hots and develop into procercoid/plerocercoid stage, $5=$ =Plerocercoid stage is eaten by fish final host, $\mathbf{6}=$ Procercoid eaten by fish intermediate host and development to plerocercoid occurs, $7=$ Eaten by final hosts (Source: Modified from Roberts 2012). 
They are predominantly found in farmed and wild fish in Asia, Africa and Europe (Rocka 2017). Cestode infestation occurs in the alimentary tract, muscles, or other internal organs. Some of the most damaging parasites of freshwater fish are larval cestodes called Plerocercoids. If Plerocercoids are present in muscles, they damage the skeleton system, and when they are present in gonadal tissue, they damage the reproductive system. Cestodes also become a major issue when they affect vital organs such as the brain, eye, or heart (Dove and Fletcher 200o). The digestive tract is the predominant site for their residence, but they do occur in other parts of the host body. For instance, Bothriocephalus acheilognothii resides in the digestive tract of host fish families Cyprinidae, Poecillidae, Cichlidae and Centrachidae (Pérez-Ponce de León et al. 2018), while Nesolecithus africanus resides in the coelomatic cavity of mormyrid Gymnachus niloticus host and Polyonchobothrium clarias resides in the gall bladder of Clarias and Oreochromis specie (Ali 2020).

Adult cestodes do not cause much damage to their host but some of them cause severe damage to fish, resulting in compromised fish quality. Like Eubothrium, chronically affect the quality of farmed fish. Polyonchobothrium clarias infests the gut mucosa of host fish and causes an inflammatory response in the gut. It also migrates towards the gall bladder and produces granulomatous nodules and fibrous tissues. Larval forms of plerocercoids and cysticercoids cause damages in freshwater fishes. In African fish, predominant infection is due to ligula plerocercoids in the body cavity of Barbus, Cyprinid species and Cyclophyllidean cysticercoids infect the mesenteries of siluriform, Clarias and Bagrus species (Song 2018). They have piscivorous birds such as gulls and cormorants as their definitive hosts. Ligula plerocercoid infects Barbus species and causes abdomen distention along with the formation of hemorrhages in the abdominal wall of the host and may also result in reproductive impairment (FAO 2015). The general life cycle of cestode parasites is elaborated in Fig. 4.

\section{Nematodes}

Nematodes are important parasites of several species of both aquaculture and wild fish. They use fish as intermediate or transient hosts and result in heavy infection, involving almost all organs of their hosts (Ali et al. 2014). Nematodes have a distinctive shape, having resistant cuticles which make them hardy and relatively last longer as compared to platyhelminths in post-mortem conditions (FAO 2015). There are 40 species of nematodes, severely infecting the digestive system of various fish species in Africa. Adult nematode usually resides in the fish digestive tract. However, different life stages may be present in internal organs, coelomic cavity, external muscle layers, the swim bladder, and inside the skin or fins, depending upon different species of nematode and infected fish (Dick and Choundury 1995). In Pakistan, 13 species of nematodes, 8 of which are new, were recovered from 15 species of fish at the Karachi coast. Camallanus cotti, Tetrahymena corlissi, and Anisakis simplex were the most common nematodes found in the intestine of wild marine (Khan and Begum 1971). In healthy fish, nematodes are often present in low numbers but can increase in number to produce serious illness or even death. If the fish is the final or conclusive host, then the nematode will go into another organism, generally a marine invertebrate like a side swimmer, side copepod, or insect larva, in which it will grow before being eaten by a fish. Upon ingestion, nematode species sexually mature and reproduce in the fish. In this situation, the fish is named as the definitive or final host (Ali et al. 2014). Nematodes, that have an indirect life cycle, use the fish as intermediate hosts. The conclusive host (that comprises the propagative adult phase of the nematode) could be a fish-eating fish, mammal, or bird. Fish nematodes have

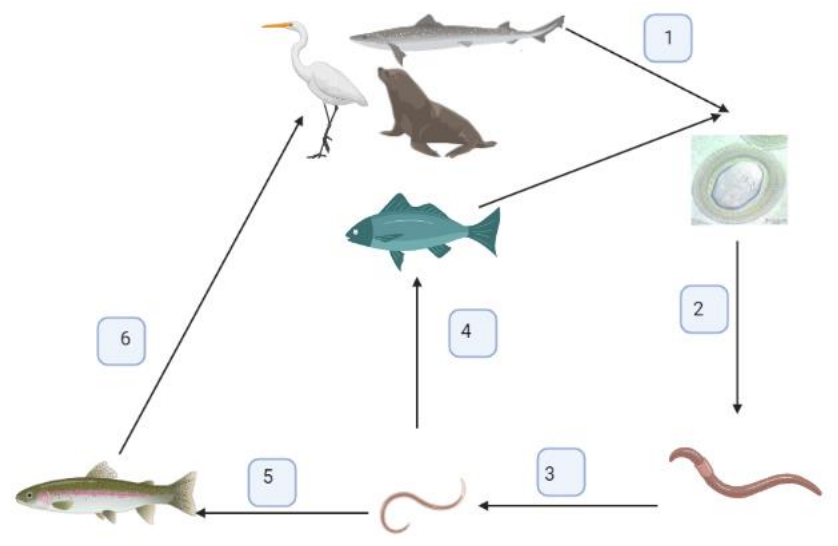

Fig. 5: Simplified life cycle patterns of nematodes parasites infecting the fish: 1=Eggs laid by adults hatch to release freeswimming larvae, $\mathbf{2}=$ Larvae eaten by invertebrate intermediate host, 3=Further larval development occurs in invertebrate host, $\mathbf{4}=$ Infective larvae eaten by fish final host, 5 =Larvae encyst in fish intermediate or paratenic host, $\mathbf{6}=$ Infective larvae eaten by final host (Source: Modified from Roberts 2012).

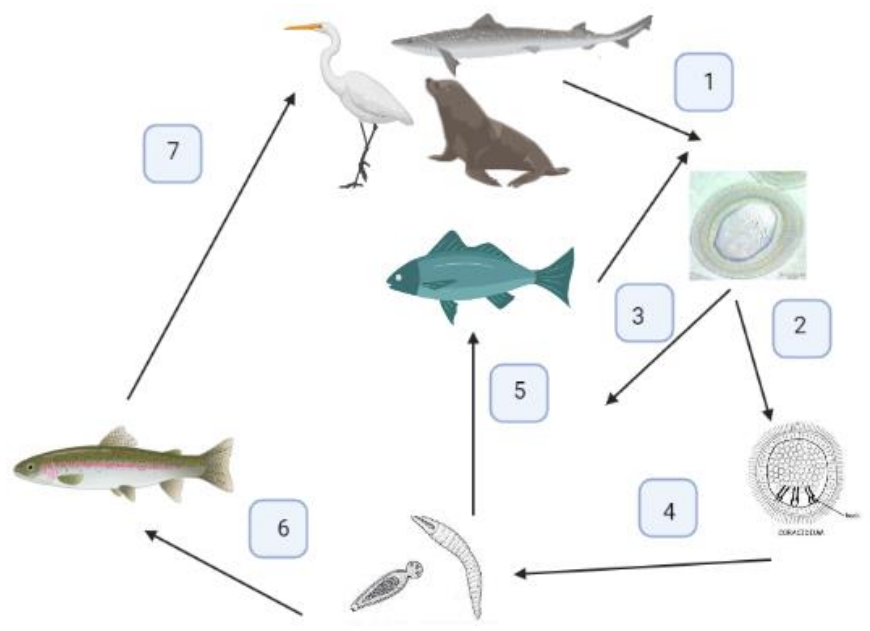

Fig. 6: Simplified life cycle patterns of acanthocephalan parasites infecting the fish: 1=Eggs laid by final adult host, $\mathbf{2}=$ Eggs hatch and release coracidium, $3=$ Eggs eaten by an invertebrate intermediate host, $4=$ Coracidium eaten by intermediate hots and develop into procercoid/plerocercoid stage, $5=$ =Plerocercoid stage is eaten by fish final host, $\mathbf{6}=$ Procercoid eaten by fish intermediate host and development to plerocercoid occurs, 7= Eaten by final hosts (Source: Modified from Roberts 2012). 
the capability to persist in alternate individuals, recognized as paratenic hosts. Such hosts are not necessary for the completion of the life cycle, but they can comprise infected nematode life stages and be a basis of infection. They can be worms, fish or further marine organisms which feed on the nematode larvae or eggs (Pazooki et al. 2012). The general life cycle of nematode parasites is elaborated in Fig. 5 .

\section{Acanthocephala}

Acanthocephalans are internal parasites of fish and amphibians and are characterized by the presence of an armed and eversible proboscis used to pierce the gut wall of fishes. These gastrointestinal parasites can cause pathological changes which may result in deterioration of the host health (Taraschewski 20o8). Parasites have the characteristic feature of a proboscis which can evaginate and is crowned with many rows of recurved hooks. Acanthocephalans are heteroxenous and they don't have alimentary canal. Eggs laid by the adult worm in the intestinal lumen are passed out through feces and enter the body of the first intermediate hosts, such as amphipods, isopods, and copepods by ingestion. Here, the hatching of eggs takes place into acanthella or acenthar, which is the first-stage larva (Kennedy 2006). Larvae develop into adult worms when an intermediated host is ingested by the definitive host, such as fish amphibians or reptiles. Due to the encapsulation of larvae in the tissue and penetration of the proboscis of adult worms in the muscular layer of the digestive tract of the host, pathological changes take place (Oniye 2004), such as widespread granuloma, followed by fibrosis inflammation, peritonitis, obstruction, and perforation of the digestive tube (Sanil 2011). African fishes (Tilapia, Barbus, Heterotis niloticus and Citherinus, Synodontis) are the final host of Acanthochala. Acanthocephlus, Paragorgorhynchus, Termisentic and Neoechinorhynchus (Valladao 2020) are the genera of acanthocephalan, which infect Tilapia, Barbus, Heterotis niloticus and Citherinus synodontis species of fish, respectively (Taraschewski 2008). The general life cycle of acanthocephalan is elaborated in Fig. 6.

\section{Some significant parasites of fish}

\section{Cryptocaryon irritans}

Cryptocaryon (C.) irritans is the cause of white spot disease in wild and cultivated marine fishes (Yin et al. 2018). It is a ciliated protozoan parasite that can survives at temperatures, ranging between $15^{\circ} \mathrm{C}$ and $30^{\circ} \mathrm{C}\left(59^{\circ} \mathrm{F}-\right.$ $\left.86^{\circ} \mathrm{F}\right)$. Cryptocaryon is known to infect several fish species and its different strains have been isolated from various parts of the world. Although, some of them possess many similar characteristics like life cycles and salinity tolerances, however, many of them are beyond the previously described "normal" ranges (Yambot et al. 2003). The parasite has a direct life cycle and transmission of infection within a group of fish does not require any other animal or host for its development (Colorni and Burgess 1997). However, complex life cycle phases develop on and off the fish host, which eventually leaves the cyst as theronts, the infective and the free-swimming stage. Theronts dynamically seek fish hosts. The trophont is the "nourishing step" and the parasite is embedded inside the tissues of the fish at this step. After leaving the fish, the trophont becomes a protomont before encysting and converting into a tomont, which is the reproductive stage. The tomont matures and divides into various tomites. The span of the whole life cycle may differ, depending upon several factors including, strain of the parasite, temperature, salinity and fish host (Yambot et al. 2003; Rigos et al. 2013). An average duration of life cycle is recorded around 1 to 2 weeks; however, it may extend up to 11 weeks. This variation in the life cycle is attributed to the uncertainty of tomont maturation (Dickerson 2006). Time required and the size at different life cycle stages may vary due to the variety of strains of $C$. irritans, temperature and salinity level of water, or maybe due to different fish species acting as hosts. The temperature range for the ideal development of most of the strains of Cryptocaryon is $23-30^{\circ} \mathrm{C}$ (Wang et al. 2018).

Infection with Cryptocaryon in most cases shows small white spots, nodules, or patches on the skin, fins, or gills of infected fish. Other symptoms include ragged fins, cloudy eyes, pale gills, increased mucus production, or changes in skin colour, and skin may also appear thin (Raga 2007; Yin et al. 2014). Behaviourally, fish may flash (scratch), swim unusually, hang at the surface or on the bottom, act lethargic or breathe more speedily in distress (Colorni and Burgess 1997).

The parasite can be diagnosed through microscopic examination (wet mount) of tissue taken from gill arch, tail fin or the body surface of the infested fish. Within a host population, Cryptocaryon may increase mortalities for several days. However, the degree of pathology may vary, depending upon the strain of parasite, the species of host (fish), previous exposure to the parasite and the water temperature. Affected fish can be transferred to freshwater for $1 \mathrm{hr}$ for 2-3 days. The other method can be used as the addition of 0.5 ppm $\mathrm{CuSO}_{4}$ in the treated water with strong aeration for 5-7 days. The water must be replaced daily during the treatment. The infected fish must be shifted to parasite-free water storage tanks 2-3 times at 3 days intervals (Martin 2015; Jiang et al. 2016).

\section{Trichodinas}

Trichodina is one of the common parasites of fishes (wild or cultured) that resides in the marine and freshwaters. These parasites are popularly known as ecto-commensals and ciliated protozoans (Martins and Ghiraldelli 2008). So far, approximately 300 species have been reported from different environments in the world (Tang and Zhao 2012). This ciliated parasite can infest the host in a very short time frame due to its direct transmission and mainly infests fish kept under sub substandard conditions (Lom 1995). It replicates by binary fission and has been the topic of great interest since the previous century (Kruger et al. 
1995). Not all trichodinids are pathogenic, most of them are non-pathogenic, but when the relationship among host/parasite/environment is broken by any of the given factors, like nutritional deficiency, low water quality, infectious and/or parasitic diseases, trichodinids proliferate and become responsible for severe epidermal lesions and disease outbreaks, as reported by Huh et al. (2005). The lesions mostly seen due to the infestation of this parasite are hyperplasia and necrosis of the epidermal cells (Hassan 1999). Trichodina is the most dominant parasite in Nile tilapia. The disease caused by Trichodina sp., is termed as Trichidiniasis and its clinical signs are abnormal coloration, lethargic movement, loss of appetite, weight loss, skin lesions, fin erosion, elevated mucus production, and gill necrosis. Gills are the main targeted organ for infestation (Biagini et al. 2009); thus, the epithelial tissue of gills is an outstanding factor to assess the properties of environmental variables, toxins, and water quality (Mazon et al. 2002). Formalin and sodium chloride are used as chemotherapeutic agents and may harm branchial tissue because these are ingredients that have a toxic influence on the fish, as detected by Mert et al. (2014). Color changes also occur in fish exposed to different doses of sodium chloride and formaldehyde.

\section{Ichthyophthirius multifiliis}

Ichthyophthirius (I.) multifiliis is an obligate parasite, ciliated protozoan of freshwater fish present in warm and humid climates. The temperature range for its outbreaks is $15-25^{\circ} \mathrm{C}$ (Noga 2014). It causes high mortality and economic downfall towards various aquaculture food fish. It also affects several aquaculture species, including grass carp, rainbow trout, channel catfish, snow trout (Mallik et al. 2015), striped catfish (Kumar et al. 2018), ornamental fish, and hatcheries (Mohammadi et al. 2012). It is present in 3 progressive stages: (1) a reproductive tomont, (2) an infective theront and (3) a parasitic trophont (Nigrelli et al. 1976). The trophont is an obligate parasitic stage and depends upon vulnerable fish for its proliferation. The theront penetrates fish epithelium and causes infection. The trophont grows in fish epithelium for 5 to 6 days; after its development the adult trophont leaves the host. Infected fish show various clinical signs including, swimming promptly and rubbing their bodies against the sides of the tanks, gasping at surface water. They become more lethargic and eventually stop feeding. Infection may occur due to lower water temperature (Ling et al. 2013). Histo-pathologically, large trophont stuck in the gills can be seen. The parasite has a C-shaped, large-sized macronucleus. The outer layer of the infected gills appears as inflamed, clubbed, and deformed. The presence of multiple trophonts at the gill lamella might be because of their rapid multiplication inside host fish. Hyperplasic and hypertrophied secondary gill lamellae can be observed. Management of water temperature is another effective way to control the multiplication of the parasite. Salt is an effective treatment for Australian warm water fish against Ich. It is inexpensive, safe, and easy to handle. A solution of $2 \%$ salt in $250 \mathrm{ppm}$ formalin has also proved very effective in lowering the burden of trophonts in Snow trout (Mallik et al. 2015). Many other chemicals like malachite green, malachite green in combination with salt or formalin, formalin, chloramine- $\mathrm{T}$, potassium permanganate, and copper sulphate have been tested to prevent Ichthyophthiriasis (Kinnunen et al. 2005).

\section{Brooklynella hostilis}

Brooklynella (B.) hostilis is the causative agent for Brooklynellosis, which is also recognized as slime-blotch or clownfish disease. In the marine aquarium, $B$. hostilis infects most teleosts. It is a kidney shaped organism and has a length of about $60-80 \mu \mathrm{m}$, with bands of cilia. $B$. hostilis belongs to the order Hartmannulidae, and genus monotypic Brooklynella, which includes only one species. It replicates by binary fission, depends on dead skin, and causes severe damage to gills (Fioravanti and Florio 2017). Common symptoms are discoloration and abnormal breathing. It can also cause cast aside skin and congestion of gills. After its reproduction, the newly formed protozoa can swim freely by using their ciliates. The parasite spreads swiftly and can get transferred to a novel host effortlessly. These tiny protozoa can get entry into an advanced host or generally they become attached to the already existing host, on which their parents were residing (Anshary 2020). While feeding upon the fish, the parasite also releases toxins that can be fatal to the fish. Free swimming protozoa can survive without a host for a short time. To make the aquarium free of this parasite, it must remain fallow (fishless) for at least four weeks to kill the remaining free-swimming parasites that will not be able to find a host to feed upon.All fish within the aquarium must be put into a quarantine tank and kept out of the main aquarium during these four weeks (Hirazawa et al. 2016).

\section{Trypanoplasma}

The kinetoplast genera Trypanosoma and Trypanoplasma are common marine and fresh-water fish parasites. Similar blood flagellates are present in Europe, Asia, and North America in freshwater and occasionally marine fishes. Trypanoplasma (T.) borreli and T. bullocki are pathogenic blood parasites, affecting cyprinids in Europe and marine flatfish in the Atlantic United States, respectively (Carrington 2017). Leeches feed on infected fish and act as an intermediate host. Infected leeches then act as vectors to infect other fishes. T. borreli possesses an indirect life cycle in leeches, especially Hemiclepis marginata. Like other flagellates, $T$. borreli has a large variety of parasitic forms present within the blood. It infects the vascular system, kidneys, and other organs. Heavily infected hosts are lethargic, emaciated, and have sunken eyes. Infected fish are anemic with damage of the excretory part of the kidney, causing osmoregulatory problems (Lom and Dykova 1992). Trypanosoma carassi can induce farreaching damage to hematopoietic tissues in goldfish, causing anemia, whilst Kamińska-Gibas et al. (2018) described a long-running decrease in hematocrit, hemoglobin, and protein levels in sculpins analytically 
infected with T. bullocki. Removal of leeches is the best way to elucidate this problem.

\section{Myxobolus cerebralis}

Myxobolus (M.) cerebralis is a parasite of the Salmonidae family, including salmon and trout (Hedrick and ElMatbouli 2002). Myxosporean causes a disease known as whirling disease. It was first described in rainbow trout in Germany, and also appeared in Europe, United States, and South Africa. There is no zoonotic importance of this parasite. Skeletal deformation and neurological damage occur by myxosporean infection. Invertebrates and vertebrates are the definitive and intermediate hosts of this parasite, respectively; either host can be called alternate host for $M$. cerebralis (El-Matbouli and Hoffmann 1998). Younger fish are more susceptible to the disease before ossification of cartilage and full development of the central nervous system (Ryce et al. 2005). Susceptibility depends upon the age of the fish. Parasites can attack fish within 2 days after hatching (Markiw 1991), this could be different for different fish species as in the case of rainbow trout. It infects until 9 weeks after hatching, while chinook salmon can become infected 3 weeks after hatch (Sollid et al. 2003). Several reports are unable to differentiate between entry of parasite and setting of the life cycle. So, in most situations, recognition is based on the transport of infected fish coming from Europe, but it may be due to the reason that the parasite does not easily inhabit the new area and it does not need further confirmation of its occurrence (South Africa, Lebanon, Morocco). In North America, its presence was first reported in 2006 in Alaska (Arsan 2007), while in Arizona, its presence was first reported in 2000 (Bartholomew and Reno 2002). Myxospore develops within the oligocheate host (Tubifex (Tu.) tubifex). The $M$. cerebralis ingestion by Tu. tubifex occurs, which leads to protuberance of the polar filaments and their spores anchor into the gut lining. Shell valves get open, binucleate sporoplasm runs away and sticks in the middle of epithelial cells. Then, inter-epithelial schizogonic multiplication of binucleate sporoplasm takes place. The plasmogamy of 2 uninucleate cells occurs to develop 1 binucleate cell stage. Both nuclei divide mitotically to produce the 4-nuclei stage. The emergence of the 4-cell stage through plasmotomy; 2 cells enfold the other 2 cells which in turn leads to the generation of early pansporocyst with 2 somatic and 2 generative cells. As a result of 3 mitotic divisions of both generative cells and 2 mitotic divisions of the somatic cells, 16 gametocytes ( $8 \alpha$ and $8 \beta)$ masked by 8 somatic cells emerge. Then the meiotic division of the 16 diploid gametocytes, 16 haploid gametocytes, and 16 polar bodies results, leading to the formation of 8 zygotes after copulation of each pair of $\alpha$ and $\beta$-gametes. The sporoblast emergence occurs after 2 mitotic divisions of the zygote, 3 pyramidally arranged cells, and one inner cell are produced. As a result of the mitotic division of the 3 peripheral cells, 3 capsulogenic and 3 valvogenic cells are formed. The valvogenic cells outstretch the capsulogenic cells, while internal cleavage of the developing sporoplasm cell generates one generative cell enfolded by one somatic cell. The sporoplasm persists unfolded in the pansporocyst till its final number of germs by recurrent mitotic divisions. The inflated mature triactinomyxon spore is formed (ElMatbouli and Hoffmann 1998).

Whirling disease is identified predominantly by persistent inflammation of the cartilage, although other clinical signs are also present. Cartilage degradation occurs after the development of lesions. Although, in mature fish, parasites are present in isolated pockets in bone and are less likely to be associated with inflammatory lesions. Parasites digest the cartilage, destroying tissue structure, outcome of which is irregular bone formation and skeletal abnormalities (Hedrick et al. 1999). Any cartilage can get an infection and it differs among salmonid species, cranial regions develop lesions (Baldwin et al. 200o) and in Yellowstone cutthroat trout lower jaw (Murcia et al. 2011). Lesions originate as small foci then get developed with time into necrosis, destroying cartilage along with tissue damage and inflammation (Baldwin et al. 2000; MacConnell and Vincent 2002). Several stages of parasites are present at a single time-older stages locate themselves enclosed and younger stages at the leading edges (Baldwin et al. 2000). No drug treatment is specifically recommended for $M$. cerebralis, many drugs have been evaluated but no drug is found satisfactory. Several drugs reduced infection and suppressed disease, but none prevented or eliminated the infection. Most of the drugs cause toxicity and reduce growth.

\section{Myxozoan parasites}

Myxozoans are protozoan parasites that largely affect the gut region of various kinds of fish, living both in fresh and marine water. The most common of these parasites is Enteromyxum (E.) leei. It is a cause of disease in cultured sea bream and other species which commonly inhabit the Mediterranean region. Parasites affect the digestive tract, leading to severe enteritis which may in worse situations lead to emaciation and death. It also causes a similar type of disease in tiger pufferfish Rea. E. leei can get transferred between hosts without the need of an intermediate host, leading to the rapid spread of the disease in the fish population (Diamant 1997). Another important myxozan parasite is E. scophthalmi that causes similar intestinal conditions in the intestinal cavity of turbot fish species (Redondo et al. 2004) and is known to have direct transmission.

\section{Neobenedenia girellae}

Neobenedenia (N.) girellae is a monogenean, warm water ectoparasite of marine cultured fish species, which affects significantly greater amberjack, representing the main bottleneck for its production (Shirakashi et al. 2013). It causes high mortality and the range is 70-100\% (Ogawa et al. 1995; Shinn et al. 2015). In early infection, the parasite gets attached to the fins and the cranial skin region, while for long-term infections it moves towards ventral and 
dorsolateral skin regions (Hirayama et al. 2009; Hirazawa et al. 2011). The life cycle is shown in Figure 4. The adult parasites attach to the epithelial surface of the fish and deposit eggs into the environment. The ciliated larvae hatch from the embryonated eggs, which are called oncomiracidia. These oncomiracidia reinfect the fish and continue the life cycle. The symptoms of fish ectoparasites are host and parasite-specific. For instance, sea liceinfected Atlantic salmon skin shows an ulcerative process resulted from the second antennae and dermatitis characterized by varied epidermal thickness, detached cells, necrosis, and mobilized leucocytes (Jones et al. 1990). Other monogenean infection, as N. amelleni, shows surface epithelium denudation and interstitial oedema in red hybrid tilapia (Oreochromis spp.) (Robinson et al. 1992). Previously, it has been stated that $N$. girellae infection affects amberjack skin and alters epidermis thickness and density of goblet cells due to distorted osmoregulatory and respiratory skin functioning (Hirayama et al. 2009; Hirazawa et al. 2016). Additionally, it causes secondary bacterial infections to the skin, observed by the revamped fish conduct; scratching its skin with the tank, resulting in major skin injuries (Ogawa et al. 1995; Hirayama et al. 2009). Hydrogen peroxide solution, when used as bath treatment along with oral administration of praziquantel, has proved to be effective to control the parasite. Moreover, acquired protection against secondary infection with the parasite was demonstrated in primed Japanese flounder (Hirazawa et al. 2016).

\section{Bolbophorus confuses}

It is a digenetic fish trematode and affects skeletal muscles and viscera of the host fish, and therefore, adversely affects fish production. It affects channel catfish (Doffitt 2020) and has a complex life cycle, involving different hosts; white pelican being the definitive host, while snail, and catfish being the first and second intermediate hosts, respectively (Outa 2020). Metacercariae affect the skin and skeletal muscles of the host, but in severe cases, they penetrate the visceral organs, like the kidney and liver, and cause channel virus disease or enteric septicemia like condition. Visceral organ involvement increases mortality rates (Kahn 2010).

\section{Posthodiplostomum cuticula}

It is also a digenean that hosts freshwater fish and causes black spot disease in them. Like other digenean, it also possesses a complex life cycle, involving three hosts (Ritossa 2013). Adult parasite affects the bird (definitive host) and eggs are released in feces that contrive the miracidia which penetrate the snail (the first intermediate host). These give rise to sporocysts which evolve into Furco-cercariae, released from the snail, penetrate the skin of fish (second intermediate host) and develop into metacercaria. They infect the skin, fins, and muscles, producing visible black cysts (melanin surrounded metacercaria so-called as black spot disease) (Ondračková 2004).

\section{Proteocephalus ambloplitis}

It is a tapeworm, belonging to a large group of cestodes that infect a variety of species. It is of serious health concern (Scholz 2019). The larval stage inhabits the ovary of the host, while adult Proteocephalus worms reside in the inner wall of the gut and shed eggs (egg-filled proglottids: body segments) with the fish feces. Eggs hatch and get dispersed in water, then taken up by the crustaceans, where they develop into larvae, procercoid. This gets entry to fish gut when fish eat crustacean and develops to plerocercoid within the host.

\section{Contracaecum rudolphii}

Contracaecum rudolphii is a nematode parasite, affecting several fish species such as Alburnoides bipunctatus, Anguilla anguilla, Barbatula barbatula, Cyprinus carpio, Gobio gobio, Perca fluviatilis, Phoxinus phoxinus, Poecilia reticulata and Tinca tinca (Moravec 2009). It infects the fish directly or indirectly i.e., by infecting the copepods that are ingested by the fish. Its life cycle involves three larval stages, the third larval stage being the infective stage of the parasite. It penetrates the intestinal wall to get access to the body cavity and to encyst the visceral organs (Baruš 2001).

\section{REFERENCES}

Abdel-Rahman SM, 2019. Evaluation of fish Capillaria spp. antigen in diagnosis of human intestinal Capillariasis. The Journal of Advances in Parasitology 1: 1-6.

Achatz TJ, 2019. Phylogenetic relationships expanded diversity and distribution of Crassiphiala spp. (Digenea, Diplostomidae), agents of black spot disease in fish. Parasitology Research 118: 2781-2787.

Agboola AF et al., 2021. Effects of dietary fish oil supplementation on performance, gut morphology, protozoan load and histopathological indices of broiler chickens. Egyptian Poultry Science Journal 41: 249-263.

Al Marjan KSN and Abdullah SMA, 2009. Some ectoparasites of the common carp (Cyprinus carpio) in Ainkawa fish hatchery, Erbil Province, Kurdistan Region, Iran. Journal of Duhok University 14: 102-107.

Alexander JD, 2020. Myxoboliosis (Myxobolus cerebralis). $1^{\text {st }}$ Edition. Climate Change and Infectious Fish Diseases, CABI publishers, Cambridge, UK, pp. 381.

Ali AH et al., 2014. Checklists of nematodes of freshwater and marine fishes of Basrah Province, Iraq. Mesopotamian Journal of Marine Sciences 29: 71-96.

Ali M, 2018. A report of occurrence of gonad infecting nematode Philometra (Costa, 1845) in host Priacanthus sp. from Pakistan. International Journal of Biology and Biotechnology 15: 575-580.

Ali ML, 2020. Two gastrointestinal parasites from freshwater sharp-tooth catfish, Clarias gariepinus (Burchell, 1822). Egyptian Journal of Aquatic Biology and Fisheries 24: 463-478.

Andronova IV and Yakimovich EA, 2019. World fish market: Current trends, state and prospects. RUDN Journal of Economics 27: 259-268. 
Anshary H, 2020. Survey on ectoparasite occurrence of fish groupers sent to Fish Quarantine Agency for diseases inspection. In IOP Conference Series: Earth and Environmental Science 564: 012061.

Antar R and Gargouri L, 2018. The diversity of teleost fish trematodes in the Bay of Bizerte, Tunisia (Western Mediterranean). Helminthologia 55: 146.

Arévalo EG, 2018. Parasitic fauna of Prochilodus nigricans (Prochilodontidae) from Brazilian Amazon floodplain lakes. Biota Amazônia 8: 19-21.

Arsan EL et al., 2007. Expanded geographical distribution of Myxobolus cerebralis: First detections from Alaska. Journal of Fish Diseases 30: 483-491.

Baldwin TJ et al., 200o. Myxobolus cerebralis infection in rainbow trout (Oncorhynchus mykiss) and brown trout (Salmo trutta) exposed under natural stream conditions. Journal of Veterinary Diagnostic Investigation 12: 312-321.

Balta F et al., 2019. Seasonal distribution of protozoan parasite infections in rainbow trout (Oncorhynchus mykiss) farms in the Eastern Black Sea of Turkey. Bulletin of the European Association of Fish Pathologists 39: 31-39.

Barčák DO, 2014. Phenotypic plasticity in Caryophyllaeus brachycollis Janiszewska, 1953 (Cestoda: Caryophyllidea): Does fish host play a role? Systematic Parasitology 88: 153-166.

Bartholomew JL and Reno PW, 2002. The history and dissemination of whirling disease. In: Whirling Disease: Reviews and current topics, Symposium 29, Bartholomew JL and Wilson JC (editors). American Fisheries Society, Maryland, USA; pp: 3-24.

Baruš VTF, 2001. Cadmium and lead concentrations in Contracaecum rudolphii (Nematoda) and its host, the cormorant Phalacrocorax carbo (Aves). Folia Parasitologica 48: 77-78.

Biagini FR et al., 2009. The use of histological, histochemical and ultra-morphological techniques to detect gill alterations in $O$. niloticus reared in treated polluted waters. Micron 40: 839-844.

Bjork SJ, 2010. Invasion of Ceratomyxa shasta (Myxozoa) and comparison of migration to the intestine between susceptible and resistant fish hosts. International Journal for Parasitology 40: 1087-1095.

Bruno DW et al., 2006. Guide to the identification of fish protozoan and metazoan parasites in stained tissue sections. Diseases of Aquatic Organisms 70: 1-36.

Buchmann K, 2002. Interactions between monogenean parasites and their fish hosts. International Journal for Parasitology 32: 309-319.

Buchmann K, 2020. Immune response to Ichthyophthirius multifiliis and role of IGT. Parasite Immunology 42: e12675.

Carrington MD, 2017. Transcriptome sequence of the bloodstream form of Trypanoplasma borreli, a hematozoic parasite of fish transmitted by leeches. Genome Announcements 5: eo1712-16.

Clifford AM et al., 2017. Flexible ammonia handling strategies using both cutaneous and branchial epithelia in the highly ammonia-tolerant Pacific hagfish. American Journal of Physiology: Regulatory, Integrative and Comparative Physiology 313: 78-90.

Colorni A, 1985. Aspects of the biology of Cryptocaryon iirritans and hypo-salinity as a control measure in cultured gilt-head sea bream Sparusaurata. Diseases of Aquatic Organisms 1: 19-22.

Diamant A, 1997. Fish-to-fish transmission of a marine myxosporean. Diseases of Aquatic Organisms 30: 99-105.

Dick TA and Choudhury A, 1995. Phylum Nematoda. In: Fish Diseases and Disorders. Chapter 11, Volume 1, Protozoan and metazoan infections, P.T.K. Woo (editor), CABI Cambridge, UK, pp: 415-466.

Dickerson HW, 2006. Ichthyophthirius multifiliis and Cryptocaryon irritans (Phylum Ciliophora). In: Fish Diseases and Disorders Volume 1: Protozoan and metazoan disorders. 2nd Edition. CAB International. Cambridge, UK, pp: 116-153.

Doffitt CM, 2020. Life history studies of two digenetic trematodes, Bolbophorus damnificus and an unknown Clinostomoid species, that infect Channel Catfish Ictalurus punctatus. Doctoral Dissertation, Mississippi State University, USA.

Dove AD and Fletcher AS, 200o. The distribution of the introduced tapeworm Bothriocephalus acheilognathi in Australian freshwater fishes. Journal of Helminthology 74: 121-127.

Dziekonska-Rynko J et al., 2008. Experimental infection of Carassius auratus [L., 1758] with the second stage larvae of the nematode Contracaecum rudolphii. Wiadomosci Parazytologiczne 54: 339-343.

Dzika ED, 2009. Description of the development of the attachment and copulatory apparatus of Dactylogyrus extensus from Cyprinus carpio var. koi. Helminthologia 46: 39-44.

El-Matbouli M and Hoffmann RW, 1998. Light and electron microscopic studies on the chronological development of Myxobolus cerebralis to the actinosporean stage in Tubifex tubifex. International Journal of Parasitology 28: 195-217.

Essetchi et al., 2003. Fish diversity and its relationship with environment variables in a West Africa basin. Hydrobiology 505: 139-146.

Eszterbauer E and Székely C, 2004. Molecular phylogeny of the kidney-Parasitic Sphaerospora renicola from common carp (Cyprinus carpio) and Sphaerospora sp. from goldfish (Carassius auratus auratus). Acta Veterinaria Hungarica 52: 469-478.

Faltýnková AP, 2020. Unexpected diversity in northern Europe: Trematodes from salmonid fishes in Iceland with two new species of Crepidostomum braun, 1900. Parasitology Research 119: 2439-2462.

FAO, 2015. FAOSTAT statistics database of the Food and Agricultural Organization of the United Nations (FAO). Rome, Italy. (http://faostat3.fao.org/>

Fioravanti ML and Florio D, 2017. Common diseases in marine ornamental fishes. Marine Ornamental Species Aquaculture 1: 347-380.

Gomes et al., 2017. Use of environmental DNA (eDNA) and water quality data to predict protozoan parasites outbreaks in fish farms. Aquaculture 479: 467-473. 
González LZ, 2005. Balantidium spp. En colon de Gallotia stehlini. Revista Canaria de las Ciencias Veterinarias 2: 36.

Gopko MM, 2020. Parasite transmission in aquatic ecosystems under temperature change: Effects of host activity and elimination of parasite larvae by filterfeeders. Oikos 129: 1531-1540.

Guagliardo SV, 2019. Pathology associated with larval Eustrongylides sp. (Nematoda: Dioctophymatoidea) infection in Galaxias maculatus (Actinopterygii: Galaxiidae) from Patagonia, Argentina. International Journal for Parasitology: Parasites and Wildlife 10: 113116.

Habib S, 2007. Studies on the helminth parasites of a freshwater fish, Wallago attu. M.Sc. Thesis, Department of Zoology, Govt. College, Lahore, Pakistan; pp: 35.

Hansen HB, 2003. Mitochondrial DNA variation of Gyrodactylus spp. (Monogenea, Gyrodactylidae) populations infecting Atlantic salmon, grayling and rainbow trout in Norway and Sweden. International Journal for Parasitology 33: 1471-1478.

Hassan MAH, 1999. Trichodiniasis in farmed freshwater Tilapia in Eastern Saudi Arabia. Journal of King Abdulaziz University, Marine Science 10: 157-168.

Hedrick et al., 1999. Comparative susceptibility of rainbow trout Oncorhynchus mykiss and brown trout Salmo trutta to Myxobolus cerebralis, the cause of salmonid whirling disease. Diseases of Aquatic Organisms 37: 173-183.

Hedrick RP and El-Matbouli M, 2002. Recent advances with taxonomy, life cycle and development of Myxobolus cerebralis in the fish and oligochaete hosts. In: American Fisheries Society Symposium: pp: 45-54.

Hirayama et al., 2009. Effect of Neobenedenia girellae (Monogenea) infection on host amberjack Serioladumerili (Carangidae). Aquaculture 288: 159-165.

Hirazawa et al., 2011. Assessment of acquired protection levels against the parasite Neobenedenia girellae (Monogenea) between body surface sites including fins of amberjack Serioladumerili (Carangidae) and the skin in response to the parasite infection. Aquaculture 310: $252-258$.

Hirazawa et al., 2016. The effects of Neobenedenia girellae (Monogenea) infection on host amberjack Serioladumerili (Carangidae): Hematological and histopathological analyses. Aquaculture 461: 32-39.

Hoole DC, 2010. Ligula intestinalis (Cestoda: Pseudophyllidea): An ideal fish-metazoan parasite model? Parasitology 137: 425-438.

Huh et al., 2005. Epidemic Trichodinosis associated with severe epidermal hyperplasia in largemouth bass, Micropterus salmoides from North Carolina USA. Journal of Wildlife Diseases 41: 647-653.

Imai ST, 200o. Tetrahymena infection in guppy, Poecilia reticulata. Fish Pathology 35: 67-72.

Iyaji FO, 20o8. Parasites and their freshwater fish host. Bio Research 6: 328-338.

Jiang et al., 2016. Placemat and rotational culturing: A novel method to control Cryptocaryon irritans infection by removing tomonts. Aquaculture 459: 84-88.
Jones et al., 1990. The histopathology associated with the juvenile stages of Lepeophtheirus salmonis on the Atlantic salmon Salmo salar L. Journal of Fish Diseases 13: 303-310.

Kahn CM, 2010. The Merck Veterinary Manual. Volume 2825, Merck, Kenilworth, NJ.

Kamińska-Gibas et al., 2018. Influence of the genetic makeup of common carp on the expression of ironrelated genes during Trypanoplasma borreli infection. Journal of Veterinary Research 62: 274-285.

Kennedy CR, 2006. Ecology of the Acanthocephala. Cambridge University Press, Cambridge, UK, pp: 189-195.

Khan D and Begum A, 1971. Helminth parasites of fishes from West Pakistan. In: Nematodes, Bulletin, Department of Zoology, University of the Punjab (New Series) (No. 5), 1-22.

Kinnunen et al., 2005. Treatment of Ichthyophthiriasis after malachitegreen. I. Concrete tanks at salmonid farms. Diseases of Aquatic Organisms 64: 69-76.

Kirk RS, 2012. Sanguinicola inermis and related species. In: Fish Parasites: Pathobiology and Protection. CABI Publishers, London, UK, pp: 270-281.

Kohn et al., 2007. South American trematodes parasites of fishes. Conselho Nacional de Desenvolvimento Cientifico e Tecnologico (CNPq), Sao Paulo, Brazil, 318.

Kruger et al., 1995. Observations on the adhesive disc of Trichodina xenopodos fantham, 1924 and $T$. heterodentata duncan, 1977. (Ciliophora: Peritrichida) during binary fission. Acta Protozoologica 34: 203-209.

Kumar et al., 2018. Occurrence of Ichthyophthiriasis in Pangasianodon hypophthalmus (Sauvage, 1878) cultured in net-cages of Maithon Reservoir, Jharkhand, India. National Academy Science Letters 41: 275-278.

Lerssutthichawal et al., 2015. Monogeneans of potentially cultured Tilapias and first record of Cichlidogyrus mbirizei in Thailand. Journal of Science and Technology 13: 543-553.

Leveque et al., 2008. Global diversity of fish (Pisces) in freshwater. Hydrobiologia 595: 545-567.

Ling et al., 2013. Antiprotozoal screening of traditional medicinal plants: Evaluation of crude extract of Psoralea corylifolia against Ichthyophthirius multifiliis in goldfish. Parasitology Research 112: 2335-2338.

Liu PF, 2020. Quantitative proteomic analysis in serum of Takifugu rubripes infected with Cryptocaryon irritans. Fish and Shellfish Immunology 104: 213-221.

Lom J and Dykova I, 1992. Protozoan parasites of fishes. Developments in Aquaculture and Fisheries Science, Amsterdam, Elsevier 26: 280.

Lom J, 1995. Trichodinidae and Other Ciliates (Phylum: Ciliophora). Fish Diseases and Disorders, protozoan and metazoan infections. CAB International, Wallingford, UK, 1: 229-262.

MacConnell E and Vincent ER, 2002. Review: The effects of Myxobolus cerebralis on the salmonid host. In: Whirling Disease: Reviews and current topics, Symposium 29 Maryland, USA: American Fisheries Society, pp: 95-107.

Maciel et al., 2018. Trichodinidae in commercial fish in South America. Reviews in Fish Biology and Fisheries 28: 33-56. 
Mallik et al., 2015. Occurrence of Ichthyophthirius multifiliis (White spot) infection in snow trout, Schizothoraxri chardsonii (Gray) and its treatment trial in control condition. Indian Journal of Animal Research 49: 227-230.

Manbe et al., 2020. Prevalence of protozoan parasites in some freshwater fishes of Dangana Lake Lapai, Niger State Nigeria. Aquaculture 4: 6.

Manickam RA, 2018. The first report of an alien parasitic nematode, Camallanus cotti isolated from the wild Giant danio fish, Devario aequipinnatus, (Teleostei: Cyprinida) from southern part of Western Ghats, India. Iranian Journal of Ichthyology 5: 250-256.

Markiw ME, 1991. Whirling Disease: Earliest susceptible age of rainbow trout to the triactinomyxid of Myxobolus cerebralis. Aquaculture 92: 1-6.

Martins ML and Ghiraldelli L, 20o8. Trichodina magna (Ciliophora: Peritrichia) from cultured Nile tilapia in the State of Santa Catarina, Brazil. Brazilian Journal of Biology 68: 169-172.

Mazon et al., 2002. Gill cellular changes induced by copper exposure in the South American tropical freshwater fish Prochilodus scrofa. Environmental Research 88: 2-63.

Méndez-Hermida FGCM, 2007. Possible involvement of Artemia as live diet in the transmission of Cryptosporidiosis in cultured fish. Parasitology Research 101: 823-827.

Mert et al., 2014. Determination of histological and genotoxic effects of formalin on Nile tilapia ( $O$. niloticus L.). Aquaculture 45: 1-10.

Mohammadi et al., 2012. Histopathological study of parasitic infestation of skin and gill on Oscar (Astronotus ocellatus) and discus (Symphysodon discus). Aquaculture, Aquarium, Conservation and Legislation 5: 88-93.

Moravec F, 2009. Experimental studies on the development of Contracaecum rudolphii (Nematoda: Anisakidae) in copepod and fish paratenic hosts. Folia Parasitologica (Praha) 56(3): 185-193.

Moreira MSF, 2017. Physiological responses of reared sea bream (Sparus aurata Linnaeus, 1758) to an Amyloodinium ocellatum outbreak. Journal of Fish Diseases 40: 1545-156o.

Murcia et al., 2011. Correlation of environmental attributes with histopathology of native Yellowstone cutthroat trout naturally infected with Myxobolus cerebralis. Diseases of Aquatic Organisms 93: 225-234.

Muzzall PM, 200o. Occurrence of Sanguinicola occidentalis in Perca flavescens and Campeloma decisum from a Michigan creek. Journal of Parasitology 86: 1360-1362.

Nakao M, 2021. Frequent infections of mountain stream fish with the amphibian acanthocephalan, Pseudo acanthocephalus toshimai (Acanthocephala: Echinorhynchidae). Parasitology International 81: 102262.

Neves LRD, 2020. Diversity of monogenean parasites on gills of fishes from the Matapi River, in the Brazilian Amazon. Revista Brasileira de Parasitologia Veterinária 29: 24-29.
Nguyen et al., 2020. Helminth infections in fish in Vietnam: A systematic review. International Journal for Parasitology: Parasites and Wildlife 14: 13-32.

Nigrelli et al., 1976. Notes on Ichthyophthyrius multifilis, a ciliate parasitic on freshwater fishes, with some remarks on possible physiological races and species. Transactions of the American Microscopical Society 95: 607-613.

Nofal MIL, 2017. Ectoparasites and bacterial co-infections causing summer mortalities among cultured fishes at Al-Manzala with special reference to water quality parameters. Life Science Journal 14: 72-83.

Noga EJ, 2014. Fish Disease: Diagnosis and Treatment. Wiley India Pvt. Ltd., New Dehli, India.

Ogawa et al., 1995. Economic costs of protistan and metazoan parasites to global mariculture. Parasitology 142: 196-270.

Ogawa K, 1998. Parasitic diseases of cultured marine fish in Japan. Fish Pathology 33: 303-309.

Ondračková GM, 2004. Posthodiplostomum cuticola (Digenea: Diplostomatidae) in intermediate fish hosts: Factors contributing to the parasite infection and prey selection by the definitive bird host. Parasitology 129: 761-777.

Oniye SJ, 2004. Helminth parasites of Clarias gariepinus (Teugels) in Zaria, Nigeria. Journal of Aquatic Sciences 19: 71-75.

Outa JO, 2020. Diversity of digenean trematode larvae in snails from Lake Victoria, Kenya: First reports and bioindicative aspects. Acta Tropica 206: 105437.

Pasnik DJ, 2005. Intestinal Coccidiosis in bluegill, Lepomis macrochirus. Journal of Parasitology 91: 967-970.

Pazooki et al., 2012. New host records for fish nematodes from Iran. Journal of Cell and Animal Biology 6: 15-20.

Pérez-Ponce de León et al., 2018. Update on the distribution of the co-invasive Schyzocotyle acheilognathi (Bothriocephalus acheilognathi), the Asian fish tapeworm, in freshwater fishes of Mexico. Journal of Helminthology 92: 279-290.

Picard-Sánchez AEB, 2020. Water temperature, time of exposure and population density are key parameters in Enteromyxum leei fish-to-fish experimental transmission. Journal of Fish Diseases 43: 491-502.

Poddubnaya LG, 2021. Ultrastructural evidence for the participation of muscle cells in the formation of extracellular matrices in Aporocotylid blood flukes (Digenea). Zoologischer Anzeiger 293: 101-111.

Purivirojkul W, 2020. New records of fish parasitic isopods (Crustacea: Isopoda) from the Gulf of Thailand. Animals 10: 2298.

Raga, 2007. Cryptocaryon irritans and Enteromyxum leei, two threats for the culture of Diplodus puntazzo in the Mediterranean. Bulletin of the European Association of Fish Pathologists 27: 242-249.

Redondo et al., 2004. Studies on transmission and life cycle of Entero-myxumscophthalmi (Myxozoa), an enteric parasite of turbot Scophthalmus maximus. Folia Parasitologica 51: 188-198.

Repullés-Albelda AM, 2008. Speciation of the Paradeontacylix spp. (Sanguinicolidae) of Seriola 
dumerili. Two new species of the genus Paradeontacylix from the Mediterranean. Parasitology International 57: 405-414.

Rigos et al., 2013. In vitro and in vivo evaluation of quinine in gilthead sea bream, Sparus aurata naturally infected with the ciliate Cryptocaryon irritans. Aquaculture 416: 185-191.

Ritossa FL, 2013. Life-cycle stages of a Posthodiplostomum species (Digenea: Diplostomidae) from Patagonia, Argentina. Journal of Parasitology 99: 777-780.

Roberts RJ, 2012. Fish pathology. 4th Edition. WileyBlackwell Publishing, John Wiley \& Sons, West Sussex, UK.

Robinson et al., 1992. Infection of Red Hybrid Tilapia with a Monogenean in coastal waters off southern Jamaica. In: Proceedings of the Gulf and Caribbean Fisheries Institute 42: 441-447.

Rocka A, 2017. Cestodes and nematodes of antarctic fishes and birds. In: Biodiversity and Evolution of Parasitic Life in the Southern Ocean. Cham Springer 9: 381.

Ryce et al., 2005. Effects of fish age versus size on the development of Whirling disease in rainbow trout. Diseases of Aquatic Organisms 63: 69-76.

Saad-Fares A, 1992. Abundance/host size relationship in a fish trematode community. Journal of Helminthology 66: 187-192.

Saha and Bandyopadhyay, 2017. Seasonal incidence of protozoan parasitic infestation in ornamental fishes of West Bengal, India. Journal of Parasitic Diseases 41: 523-526.

Salgado-Maldonado GL, 2003. The Asian fish tapeworm Bothriocephalus acheilognathi: A potential threat to native freshwater fish species in Mexico. Biological Invasions 5: 261-268.

Sanil NK, 2011. Pathological manifestations of the acanthocephalan parasite, Tenuiproboscis sp. in the mangrove red snapper (Lutjanus argentimaculatus) (Forsskål, 1775), a candidate species for aquaculture from Southern India. Aquaculture 310: 259-266.

Santos et al., 2018. Protozoan and metazoan parasites of juvenile tambaqui Colossoma macropomum farmed in the lower São Francisco, Brazil. Acta of Fisheries and Aquatic Resources 6: 29-34.

Scholz T, 1999. Life cycles of species of Proteocephalus, parasites of fishes in the Palearctic Region: A review. Journal of Helminthology 73: 1-19.

Scholz TC, 2009. Update on the human broad tapeworm (genus diphyllobothrium), including clinical relevance. Clinical Microbiology Reviews 22: 146-16o.

Scholz TC, 2019. The Proteocephalus species-aggregate in freshwater centrarchid and percid fishes of the Nearctic region (North America). Journal of Parasitology 105: 798-812.

Selbach CS, 2020. Hidden parasite diversity in a European freshwater system. Scientific Reports 10: 1-14.

Shirakashi et al., 2013. Diurnal pattern of skin fluke infection in cultured amberjack, Serioladumerili, at different water depths. Aquaculture 402-403: 19-23.

Shirakashi ST, 2016. Discovery of intermediate hosts for two species of blood flukes Cardicola orientalis and Cardicola forsteri (Trematoda: Aporocotylidae) infecting Pacific bluefin tuna in Japan. Parasitology International 65: 128-136.

Šimková AB, 2017. Host-specific Dactylogyrus parasites revealing new insights on the historical biogeography of Northwest African and Iberian cyprinid fish. Parasites Vectors 10: 1-16.

Sollid et al., 2003. Age-dependent susceptibility of Chinook salmon to Myxobolus cerebralis and effects of sustained parasite challenges. Journal of Aquatic Animal Health 15: 136-146.

Song HB, 2018. Infection status with plerocercoid of ligulid tapeworm in cyprinid fish from three lakes in Republic of Korea. Helminthologia 55: 251.

Tang FH and Zhao YJ, 2012. Two trichodinids of Paratrichodina (Ciliophora, Peritrichida, Trichodinidae) infecting gills of Ietalurus punetaus from Chongqing, China. African Journal of Microbiology Research 6: 2145-2149.

Taraschewski H, 20o8. Acanthocephala. In: Fish Diseases. CRC Press 2: 1039-1076.

Tedesco et al., 2017. A global database on freshwater fish species occurrence in drainage basins. Scientific Data 4: 1-6.

Valladao GM, 2020. Challenges in the control of acanthocephalosis in aquaculture: Special emphasis on Neoechinorhynchus buttnerae. Reviews in Aquaculture 12: 1360-1372.

Vyhlídalová T, 2020. Species-specific patterns in cercarial emergence of Diplostomum spp. From snails Radix lagotis. International Journal for Parasitology 50: 11771188.

Wang et al., 2018. Effects of temperature and host species on the life cycle of Cryptocaryon irritans. Aquaculture 485: 49-52.

Wang et al., 2019. Immune responses of fish to Ichthyophthirius multifiliis (Ich): A model for understanding immunity against protozoan parasites. Developmental \& Comparative Immunology 93: 93-102.

Williams CF, 2011. Spironucleus species: Economically important fish pathogens and enigmatic single-celled eukaryotes. Journal of Aquaculture Research and Development DOI:10.4172/2155-9546.S2-002.

Williams $\mathrm{H}$ and Jones A, 1994. Parasitic worms of fish. Taylor and Francis, Ltd., London, UK, pp: 593.

Woo PT, 2003. Cryptobia (Trypanoplasma) salmositica and salmonid cryptobiosis. Journal of Fish Diseases 26: 627-46.

Yambot et al., 2003. Characterization of Cryptocaryon irritans, a parasite isolated from marine fishes in Taiwan. Diseases of Aquatic Organisms 54: 147-156.

Yin et al., 2014. Effects of Cryptocaryon irritans infection on the survival, feeding, respiratory rate and ionic regulation of the marbled rockfish Sebastiscus marmoratus. Parasitology 141: 279-286.

Yin et al., 2018. Comparison of the susceptibility and resistance of four marine perciform fishes to Cryptocaryon irritans infection. Fish and Shellfish Immunology 77: 298-303.

Younis AE, 2017. The occurrence of Contracaecum sp. larvae (Nematoda: Anisakidae) in four teleostean species from Lake Nasser, Egypt: Morphological and molecular studies. The Journal of Basic and Applied Zoology 78: Article No. 9. 